\title{
Pengaruh Lama Perebusan Kedelai Terhadap Karakteristik Kedelai Terfermentasi
}

\author{
The Effect of The Duration of Boiling Soybeans on The Characteristics of Fermented Soybeans
}

\author{
Betari Nurrachmah Kusuma Putri ${ }^{1}$, I Putu Suparthana ${ }^{1 *}$, Luh Putu Trisna Darmayanti ${ }^{1}$ \\ Program Studi Teknologi Pangan, Fakultas Teknologi Pertanian, Universitas Udayana \\ Kampus Bukit Jimbaran, Badung-Bali \\ *Penulis korespondensi: I Putu Suparthana, Email: suparthana@unud.ac.id
}

\begin{abstract}
This study aims to determine the effect of boiling time of soybean to getting the best fermented soybean characteristics. The design used in this study was a Completely Randomized Design (CRD) with duration of boiling soybeans consisting of 5 levels; 60 minutes, 90 minutes, 120 minutes, 150 minutes, and 180 minutes. This reserach was repeated three times to obtain 15 experimental units. The data obtained were analyzed by analysis of variance and if the treatment had a significant effect, it was continued with the Duncan Multiple Range (DMRT) test. The results showed that 150 minutes of boiling soybean was the best treatment with the criteria of $31,02 \%$ mositure content, $1,41 \%$ ash content, $18,00 \%$ protein content, $15,08 \%$ fat content, $34,02 \%$ carbohydrate content, light brown color, has a distinctive odor of fermented soybean, has a soft texture, and overall like reception.
\end{abstract}

Keywords: Fermented soybean, boiling time of soybean

\section{PENDAHULUAN}

Kedelai merupakan jenis kacang-kacangan yang dapat digunakan sebagai sumber protein, lemak, vitamin, mineral dan serat dikarenakan sumber gizi beragam yang terkandung di dalam kedelai. Kedelai dapat diproses menjadi bahan makanan dengan berbagai cara, diantaranya dengan penghancuran, perebusan, peragian, fermentasi dan pengasaman, sehingga menghasilkan produk tahu, kembang tahu, susu, kecap dan produk lainnya (Nugroho, 2007). Pengolahan kedelai dengan cara fermentasi dapat meningkatkan daya cerna zat gizi di dalamnya sehingga menghasilan pangan yang sehat. Menurut Yuningsih (2006) pangan fermentasi merupakan makanan yang baik untuk kesehatan karena banyak mengandung vitamin, asam amino, dan enzim yang diproduksi selama proses fermentasi. Pada pengolahan kedelai dengan cara fermentasi, terdapat berbagai jenis mikroba yang berperan pada jenis substrat yang berbeda, seperti kapang pada pembuatan tempe dan bakteri pada pembuatan natto. Natto adalah makanan hasil fermentasi khas Jepang berbahan dasar kacang kedelai dalam bentuk terurai, berlendir dan beraroma sangat tajam. Natto memiliki kemiripan dengan pangan tradisional dari Bali, dari proses produksi hingga produk akhir yang dihasilkan, yakni sere kedele. Akan tetapi sere kedele biasanya memiliki tahap lanjutan seperti penambahan bumbu atau digoreng.

Pengujian nilai gizi sere kedele dengan penambahan bumbu yang berbeda pernah dilakukan oleh Walianingsih (2015) diproduksi di 
laboratorium secara spontan, yakni tanpa penambahan starter atau isolat dan mikroba tumbuh secara alami. Produksi sere kedele secara spontan belum memperhatikan faktor yang dapat berpengaruh terhadap nilai gizi kedelai apabila akan dibuat menjadi sere kedele, seperti lama perebusan kedelai. Perebusan kedelai pada pembuatan sere kedele secara spontan di wilayah Gianyar umumnya berkisar 2 hingga 4 jam. Perebusan kedelai yang cukup lama tersebut dapat mempengaruhi nilai gizi yang terkandung di dalam kedelai, seperti penurunan kandungan protein karena denaturasi protein dan penurunan kandungan lemak karena proses hidrolisis. Proses perebusan kedelai juga dapat menghilangkan kandungan mineral yang mudah larut dalam air. Dian Sundari, dkk (2015) menyebutkan bahwa proses perebusan dan penggorengan diperkirakan akan merusak sebagian zat gizi bahan pangan, diantaranya vitamin dan protein. Penurunan mineral berkisar antara 5-40\%, terutama kalsium, yodium, seng, selenium dan zat besi. Selain itu proses perebusan kedelai yang lama juga dapat mempengaruhi bobot akhir kedelai karena selama perebusan terjadi penyerapan air ke dalam jaringan kedelai sehingga menambah nilai kadar air kedelai setelah direbus.

Berdasarkan hal tersebut, lama perebusan kedelai dapat mempengaruhi karakteristik akhir kedelai apabila akan dilakukan pengolahan lanjutan, dalam hal ini sere kedele. Penelitian ini bertujuan untuk mengetahui pengaruh lama perebusan kedelai dan menentukan lama waktu perebusan kedelai yang tepat untuk mendapatkan karakteristik kedelai terfermentasi terbaik yang nantinya akan berpegaruh terhadap karakteristik akhir sere kedele.

\section{METODE PENELITIAN}

\section{Tempat dan Waktu}

Penelitian ini dilaksanakan di Laboratorium Pengolahan Pangan, Laboratorium Mikrobiologi dan Laboratorium Analisis Pangan, Fakultas Teknologi Pertanian, Universitas Udayana yang berlokasi di Jalan P.B. Sudirman, Denpasar Barat. Penelitian ini dilaksanakan pada Bulan September hingga Oktober 2020.

\section{Bahan dan Alat}

Bahan yang digunakan dalam pembuatan kedelai terfermentasi adalah kacang kedelai varietas merbabu yang diperoleh dari Pusat Perbelanjaan Swalayan Carrefour serta starter padat berupa kedelai yang telah terfermentasi selama 24 jam, diperoleh dari produsen sere kedele di wilayah BlahBatuh, Gianyar. Media pertumbuhan yang digunakan untuk pengujian total mikroba menggunakan Plate Count Agar (PCA). Bahan-bahan yang digunakan untuk analisis yaitu $\mathrm{NaOH} 50 \%, \mathrm{HCl} 0,1 \mathrm{~N}$, aquades, pelarut n-heksan, $\mathrm{H}_{2} \mathrm{SO}_{4}$ pekat, tablet Kjeldahl, indikator phenolphthalein (PP), asam borat $3 \%$.

Alat Alat yang digunakan untuk pembuatan kedelai terfermentasi yaitu waskom, mangkuk, panci, kompor gas (Covina), gas lpj $5 \mathrm{~kg}$, inkubator. Peralatan yang digunakan untuk analisis kimia adalah timbangan analitik (Shimadzu ATY224), lumpang, oven (Cole-Parmer), cawan porselin, alumunium foil, desikator, crus porselin, labu erlenmeyer $250 \mathrm{ml}$ (Pyrex), alat destilasi Soxhlet (behro test), pipet volume $5 \mathrm{ml}$, kertas 
saring biasa, benang wol, gelas ukur $100 \mathrm{ml}$ (Pyrex), gelas ukur $50 \mathrm{ml}$ (Pyrex), gelas beker 100 $\mathrm{ml}$ (Pyrex), alat titrasi, muffle, hot plate, labu protein (Pyrex), labu lemak (Pyrex) dan labu Kjeldahl. Sedangkan peralatan yang digunakan untuk analisis mikrobiologi yaitu laminar airflow (Kojair), minimix, autoklaf (Hirayama), sterilisator (Electra), freezer, erlemeyer $250 \mathrm{ml}$ (Pyrex), gelas ukur $100 \mathrm{ml}$ (Pyrex),tabung eppendorf $1 \mathrm{ml}$, tabung sentrifugasi, cawan petri, rak tabung, bunsen, aluminium foil, gelas beker $1000 \mathrm{ml}$ (Phyrex), batang pengaduk, kompor listtrik (rinnai), tip kuning, tip biru, pipet mikro, batang bengkok, plastik, kertas label, dan kapas.

\section{Rancangan Penelitian}

Rancangan yang digunakan pada penelitian ini adalah Rancangan Acak Lengkap (RAL) dengan faktor perlakuan lama perebusan kedelai yang terdiri dari lima taraf yaitu; 60 menit, 90 menit, 120 menit, 150 menit, 180 menit dan diulang sebanyak 3 kali sehingga diperoleh 15 unit percobaan.

\section{Analisis Data}

Pada pengujian proksimat dan sensoris, data yang diperoleh dianalisis dengan analisis ragam (ANOVA) dan apabila perlakuan berpengaruh terhadap variabel yang diamati maka dilanjutkan dengan Uji Jarak Berganda Duncan (Gomez dan Gomez, 1995). Pengujian total mikroba menggunakan Total Plate Count (TPC) dan data yang diperoleh dianalis menggunakan analsis Sample T-Test (Yunita, dkk., 2015).

\section{Variabel yang Diamati}

Adapun variabel yang diamati dalam penelitian ini meliputi kadar air menggunakan metode oven, kadar abu dengan metode pengabuan, kadar protein dengan metode Mikro Kjeldhal, kadar lemak dengan metode Soxhlet, dan kadar karbohidrat menggunakan analisis proksimat (Sudarmadji, et al 1997). Total mikroba (total plate count) dengan metode cawan tuang (Yunita, et al, 2015), dan sifat sensoris menggunakan uji skoring terhadap warna, aroma, tekstur dan penerimaan keseluruhan (Soekarto, 1985).

\section{Pelaksanaan Penelitian}

Pembuatan kedelai terfermentasi mula-mula proses persiapan bahan meliputi sortasi dan penimbangan jumlah bahan sesuai dengan formula yang telah ditentukan. Kedelai (150 g) yang telah disortasi kemudian dicuci menggunakan air bersih dengan perbandingan 1 bagian kedelai : 2 bagian air. Kedelai lalu direndam selama 8 jam dengan perbandingan 1 bagian kedelai : 3 bagian air. Lalu direbus menggunakan air dengan perbandingan 1 bagian kedelai : 20 bagian air dengan suhu $100^{\circ} \mathrm{C}$ selama 60 menit, 90 menit, 120 menit, 150 menit dan 180 menit. Kedelai yang sudah matang kemudian ditiriskan hingga sedikit dingin. Selanjutnya, kedelai yang telah direbus ditimbang seberat 300 gram dan dimasukkan ke dalam mangkuk, lalu ditambahkan starter berupa kedelai terfermentasi dari produsen sere kedele (belum ditambahkan bumbu). Starter padat dengan konsentrasi 30\% (90 gram) ditambahkan dan diaduk hingga merata. Kemudian mangkuk ditutup menggunakan aluminium foil dan bagian atas aluminium foil diberi lubang sama rata pada setiap perlakuan, yakni sebanyak 10 lubang. Kemudian difermentasi menggunakan alat inkubator dengan suhu fermentasi $40^{\circ} \mathrm{C}$ selama 24 jam. 


\section{HASIL DAN PEMBAHASAN}

\section{Hasil Analisis Kedelai Terfermentasi}

Nilai rata-rata kadar air, kadar abu, kadar protein, kadar lemak dan kadar karbohidrat dari kedelai terfermentasi dengan lama perebusan berbeda yang dibuat di laboratorium dapat dilihat pada Tabel 1. Nilai rata-rata skor terhadap warna, aroma dan tekstur kedelai terfermentasi dengan lama perebusan berbeda dapat dilihat pada Tabel 2 . Sedangkan hasil uji sensoris terhadap penerimaan keseluruhan kedelai terfermentasi dengan lama perebusan berbeda dapat dilihat pada Tabel 3.

Tabel 1. Nilai rata-rata kadar air, kadar abu, kadar protein, kadar lemak dan kadar karbohidrat dari kedelai terfermentasi.

\begin{tabular}{cccccc}
\hline $\begin{array}{c}\text { Perlakuan } \\
\text { lama } \\
\text { perebusan } \\
\text { (menit) }\end{array}$ & $\begin{array}{c}\text { Kadar Air } \\
(\%)\end{array}$ & $\begin{array}{c}\text { Kadar Abu } \\
(\%)\end{array}$ & $\begin{array}{c}\text { Kadar Protein } \\
(\%)\end{array}$ & $\begin{array}{c}\text { Kadar Lemak } \\
(\%)\end{array}$ & $\begin{array}{c}\text { Kadar } \\
\text { Karbohidrat } \\
(\%)\end{array}$ \\
\hline P1 (60) & $21,45 \pm 0,88^{\mathrm{e}}$ & $1,53 \pm 0,00^{\mathrm{a}}$ & $23,03 \pm 0,01^{\mathrm{a}}$ & $17,33 \pm 0,08^{\mathrm{a}}$ & $36,67 \pm 0,10^{\mathrm{a}}$ \\
P2 (90) & $25,47 \pm 0,56^{\mathrm{d}}$ & $1,50 \pm 0,00^{\mathrm{b}}$ & $21,17 \pm 0,15^{\mathrm{b}}$ & $16,74 \pm 0,10^{\mathrm{b}}$ & $35,12 \pm 0,11^{\mathrm{b}}$ \\
P3 (120) & $28,51 \pm 0,45^{\mathrm{c}}$ & $1,48 \pm 0,00^{\mathrm{b}}$ & $19,37 \pm 0,02^{\mathrm{c}}$ & $15,79 \pm 0,18^{\mathrm{c}}$ & $34,85 \pm 0,10^{\mathrm{c}}$ \\
P4 (150) & $31,02 \pm 0,12^{\mathrm{b}}$ & $1,41 \pm 0,00^{\mathrm{c}}$ & $18,47 \pm 0,34^{\mathrm{d}}$ & $15,08 \pm 0,08^{\mathrm{d}}$ & $34,02 \pm 0,43^{\mathrm{d}}$ \\
P5 (180) & $35,45 \pm 0,40^{\mathrm{a}}$ & $1,37 \pm 0,02^{\mathrm{d}}$ & $15,41 \pm 0,51^{\mathrm{e}}$ & $14,12 \pm 0,09^{\mathrm{e}}$ & $33,65 \pm 0,05^{\mathrm{e}}$ \\
\hline
\end{tabular}

Keterangan: Nilai rata-rata yang diikuti oleh huruf yang berbeda pada kolom yang sama menunjukkan perbedaan nyata $(\mathrm{P}<0,05)$.

\section{Kadar Air}

Hasil analisis ragam menunjukkan bahwa perlakuan lama perebusan kedelai berpengaruh sangat nyata $(\mathrm{P}<0,01)$ terhadap kadar air kedelai terfermentasi. Berdasarkan Tabel 1 hasil menunjukkan bahwa nilai rata-rata kadar air pada kedelai terfermentasi dengan berbagai perlakuan lama perebusan, nilai tertinggi adalah perlakuan P5 (180 menit) sebesar $35,45 \%$ dan nilai terendah adalah perlakuan P1 (60 menit) sebesar 21,45\%.

Pada Tabel 1 data menunjukkan bahwa semakin lama perebusan maka kadar air kedelai terfermentasi semakin meningkat. Perbedaan nilai rata-rata kadar air pada kedelai disebabkan karena perbedaan penyerapan air ke dalam biji dan perbedaan pengembangan biji kedelai pada masing-masing perlakuan perebusan. Pada saat perebusan kedelai, air akan masuk ke dalam biji kedelai sehingga akan menambah bobot air di dalamnya dan kadar air akan meningkat (Kusumawati, 2019).

\section{Kadar Abu}

Hasil analisis ragam menunjukkan bahwa perlakuan lama perebusan kedelai berpengaruh sangat nyata $(\mathrm{P}<0,01)$ terhadap kadar abu kedelai terfermentasi. Berdasarkan Tabel 1 hasil menunjukkan bahwa nilai rata-rata kadar abu pada kedelai terfermentasi dengan berbagai perlakuan lama perebusan, nilai tertinggi adalah perlakuan P1 (60 menit) sebesar 1,53\% dan nilai terendah adalah perlakuan P5 (180 menit) sebesar 1,37\%.

Pada Tabel 1 dapat dilihat bahwa nilai kadar abu semakin turun seiring dengan lama perebusan yang dilakukan. Kadar abu menunjukkan kandungan mineral yang terkandung dalam suatu bahan pangan, lama perebusan akan membuat 
kandungan mineral dalam biji kedelai larut ke dalam air. Sehingga semakin lama perebusan maka semakin banyak mineral yang terlarut ke dalam air dan membuat kadar abu biji kedelai menurun. Fennema (1996) menyebutkan bahwa kandungan mineral dalam bahan pangan tidak dapat rusak oleh cahaya, agen pengoksidasi, dan $\mathrm{pH}$ yang ekstrim. Namun, hilangnya mineral lebih disebabkan oleh pencucian atau proses pemanasan. Penurunan pada kadar abu kedelai terfermentasi mengindikasikan bahwa mineral yang terkandung dalam kedelai banyak terdapat pada lapisan kulit ari kedelai. Hal tersebut diperkuat oleh pernyataan Fennema (1996) yang menyatakan bahwa mineral pada kacang-kacangan dan biji-bijian terkonsentrasi pada bagian kulit dan lapisan ari sehingga mudah hilang pada proses pencucian atau pemanasan.

\section{Kadar Protein}

Hasil analisis ragam menunjukkan bahwa perlakuan lama perebusan kedelai berpengaruh sangat nyata $(\mathrm{P}<0,01)$ terhadap kadar protein kedelai terfermentasi. Berdasarkan Tabel 1 hasil menunjukkan bahwa nilai rata-rata kadar protein pada kedelai terfermentasi dengan berbagai perlakuan lama perebusan, nilai tertinggi adalah perlakuan P1 (60 menit) sebesar 23,03\% dan nilai terendah adalah perlakuan P5 (180 menit) sebesar $15,41 \%$.

Protein merupakan zat gizi makro yang diunggulkan pada produk berbahan dasar kedelai. Kandungan protein dalam kedelai menunjukkan kualitas kedelai tersebut. Pada Tabel 1 dapat dilihat bahwa seiring lama perebusan maka nilai rata-rata kadar protein semakin menurun. Hal ini dikarenakan proses perebusan dapat merusak struktur protein yang terdapat di dalam kedelai, perebusan menggunakan suhu tinggi mengakibatkan denaturasi protein sehingga kadar protein di dalam kedelai menjadi turun. Hal ini diperkuat oleh penelitian yang dilakukan oleh Yazid dan Nursanti (2006) bahwa protein yang mengalami denaturasi akan menurunkan aktivitas biologinya dan berkurang kelarutannya, sehingga akan mengendap. Kristiningrum dan Susanto (2015) menyebutkan semakin lama perebusan maka semakin banyak protein yang mengalami kerusakan.

\section{Kadar Lemak}

Hasil analisis ragam menunjukkan bahwa perlakuan lama perebusan kedelai berpengaruh sangat nyata $(\mathrm{P}<0,01)$ terhadap kadar lemak kedelai terfermentasi. Berdasarkan Tabel 1 hasil menunjukkan bahwa nilai rata-rata kadar lemak pada kedelai terfermentasi dengan berbagai perlakuan lama perebusan, nilai tertinggi adalah perlakuan P1 (60 menit) sebesar 17,33\% dan nilai terendah adalah perlakuan P5 (180 menit) sebesar $14,12 \%$.

Pada Tabel 1 dapat dilihat bahwa kadar lemak semakin turun seiring dengan lama perebusan. Hal ini dikarenakan proses perebusan menyebabkan terjadi perubahan struktur lemak di dalam kedelai karena terjadi proses hidrolisis lemak, lemak akan diubah menjadi asam lemak bebas dan gliserol. Hal ini sejalan dengan Winarno (1997), bahwa dengan adanya pemanasan menggunakan air, lemak dapat terhidrolisis menjadi gliserol dan asam lemak yang kemudian hilang selama perebusan berlangsung. 


\section{Kadar Karbohidrat}

Hasil analisis ragam menunjukkan bahwa perlakuan lama perebusan kedelai berpengaruh sangat nyata $(\mathrm{P}<0,01)$ terhadap kadar karbohidrat kedelai terfermentasi. Berdasarkan Tabel 1 hasil menunjukkan bahwa nilai rata-rata kadar karbohidrat pada kedelai terfermentasi dengan berbagai perlakuan, nilai tertinggi adalah perlakuan P1 (60 menit) sebesar 36,67\% dan nilai terendah adalah perlakuan P5 (180 menit) sebesar 33,65\%.
Pada Tabel 1 dapat dilihat bahwa nilai ratarata kadar karbohidrat semakin menurun seiring lamanya lama perebusan. Hal ini dikarenakan banyaknya molekul karbohidrat yang terdegradasi menjadi molekul-molekul gula yang sederhana. Selain itu penurunan kadar karbohidrat juga disebabkan oleh sebagian kandungan oligosakarida pada kedelai hilang dalam proses perendaman dan perebusan.

Tabel 2. Nilai rata-rata skor terhadap warna, aroma dan tekstur dari kedelai terfermentasi.

\begin{tabular}{cccc}
\hline $\begin{array}{c}\text { Perlakuan lama } \\
\text { perebusan (menit) }\end{array}$ & $\begin{array}{c}\text { Warna } \\
*\end{array}$ & $\begin{array}{c}\text { Aroma } \\
* *\end{array}$ & $\begin{array}{c}\text { Tekstur } \\
* * *\end{array}$ \\
\hline P1 (60) & $1,50 \pm 0,68^{\mathrm{e}}$ & $2,40 \pm 0,50^{\mathrm{c}}$ & $1,40 \pm 0,50^{\mathrm{d}}$ \\
P2 (90) & $2,50 \pm 0,51^{\mathrm{d}}$ & $1,50 \pm 0,60^{\mathrm{e}}$ & $2,30 \pm 0,47^{\mathrm{c}}$ \\
P3 (120) & $2,60 \pm 0,82^{\mathrm{cd}}$ & $3,30 \pm 0,5^{7 \mathrm{~b}}$ & $2,20 \pm 0,41^{\mathrm{c}}$ \\
P4 (150) & $3,30 \pm 0,73^{\mathrm{a}}$ & $4,20 \pm 0,89^{\mathrm{a}}$ & $3,20 \pm 0,41^{\mathrm{b}}$ \\
P5 (180) & $3,00 \pm 0,72^{\mathrm{ab}}$ & $1,60 \pm 0,50^{\mathrm{de}}$ & $4,00 \pm 0,44^{\mathrm{a}}$ \\
\hline
\end{tabular}

Keterangan: Nilai rata-rata yang diikuti oleh huruf yang berbeda pada kolom yang sama menunjukkan perbedaan nyata.

* 1 = kuning, $2=$ kuning kecoklatan, $3=$ coklat muda, $4=$ coklat tua

** $1=$. Tidak khas kedelai terfermentasi, $2=$ Agak tidak khas kedelai terfermentasi, $3=$ Agak khas kedelai terfermentasi, $4=$ Khas kedelai terfermentasi, $5=$ Sangat khas kedelai terfermentasi

*** 1 = Tidak empuk, 2 = Agak Empuk, 3 = Empuk, 4 = Sangat empuk

Tabel 3. Nilai rata-rata uji hedonik terhadap penerimaan keseluruhan kedelai terfermentasi

\begin{tabular}{cc}
\hline Perlakuan lama perebusan (menit) & Penerimaan Keseluruhan \\
& $1,6 * * *$ \\
\hline P1 (60) & $2,10 \pm 0,74^{\mathrm{d}}$ \\
P2 (90) & $2,05 \pm 0,35^{\mathrm{c}}$ \\
P3 (120) & $5,00 \pm 0,47^{\mathrm{a}}$ \\
P4 (150) & $4,00 \pm 0,44^{\mathrm{b}}$ \\
P5 (180)
\end{tabular}

Keterangan: Nilai rata-rata yang diikuti oleh huruf yang berbeda pada kolom yang sama menunjukkan perbedaan nyata.

$* * * * 1=$ Tidak suka, $2=$ Agak tidak suka, $3=$ Biasa, $4=$ Agak suka, $5=$ Suka

\section{Evaluasi Sensoris}

\section{Warna}

Hasil analisis ragam pada Tabel 2 menunjukkan bahwa perlakuan lama perebusan berpengaruh sangat nyata $(\mathrm{P}<0,01)$ terhadap warna kedelai terfermentasi. Nilai rata-rata warna tertinggi yaitu pada perlakuan P4 (150 menit) sebesar 3,30\% dengan kriteria coklat muda dan 
nilai rata-rata terendah yaitu pada perlakuan P1 (60 menit) sebesar 1,50\% dengan kriteria kuning.

Pada Tabel 2 dapat dilihat bahwa terjadi perubahan warna seiring dengan bertambahnya lama perebusan, yakni dari berwarna kuning hingga menjadi berwarna coklat. Nilai rata-rata warna terendah yaitu pada perlakuan P1 (60 menit) dengan kriteria kuning. Hal ini dikarenakan warna pada perlakuan P1 masih seperti kedelai yang belum difermentasi, lama perebusan yang sebentar membuat pigmen pada kedelai masih cukup baik. Nilai rata-rata warna tertinggi pada perlakuan P4 (150 menit) memiliki warna yang mendekati dengan warna kedelai terfermentasi yang diproduksi oleh produsen, sehingga hal tersebut diduga sebagai penyebab panelis memberikan penilaian tinggi terhadap warna untuk perlakuan $\mathrm{P} 4$ (150 menit). Selain itu, pada dasarnya lama perebusan dapat menyebabkan terjadinya perubahan warna pada kacang kedelai. Hal ini dikarenakan pigmen yang terdapat pada kacang kedelai akan semakin rusak dan warna kedelai akan menjadi pucat seiring dengan meningkatnya lama perebusan. Hal ini sesuai dengan penelitian yang dilakukan oleh Mulyatiningsih (2007) bahwa bahan pangan akan terlihat kurang menarik apabila proses perebusan terlalu lama karena terjadi perubahan warna dikarenakan pigmen pada bahan pangan bersifat tidak stabil pada saat proses pemasakan.

\section{Aroma}

Hasil analisis ragam pada Tabel 2 menunjukkan bahwa perlakuan lama perebusan berpengaruh sangat nyata $(\mathrm{P}<0,01)$ terhadap aroma kedelai terfermentasi. Nilai rata-rata aroma tertinggi yaitu pada perlakuan P4 (150 menit) sebesar 4,20\% dengan kriteria khas kedelai terfermentasi dan nilai rata-rata terendah yaitu pada perlakuan P2 (90 menit) sebesar 1,50\% dengan kriteria tidak khas kedelai terfermentasi.

Pada Tabel 2 dapat dilihat bahwa terjadi perubahan aroma seiring dengan bertambahnya lama perebusan, yakni dari aroma tidak khas kedelai terfermentasi hingga khas kedelai terfermentasi. Perlakuan P2 (90 menit) dengan kriteria tidak khas kedelai fermentasi mendapat nilai rata-rata aroma terendah. Hal ini dikarenakan lama perebusan selama 90 menit hanya sedikit perombakan zat gizi dan daya cerna yang terjadi di dalam kedelai, sehingga pada saat fermentasi berlangsung, mikroba belum dapat memecah substrat di dalam kedelai secara sempurna dan menyebabkan hanya sedikit bau yang dihasilkan dan tercium pada saat panelis memberikan penilaian. Sedangkan nilai rata-rata aroma tertinggi yaitu pada perlakuan P4 (150 menit) sebesar 4,20\% dengan kriteria khas kedelai terfermentasi disebabkan karena lama perebusan selama 150 menit telah terjadi perombakan zat gizi di dalam kedelai, sehingga pada saat fermentasi berlangsung, aroma yang dihasilkan lebih tajam. Menurut Sarti dkk, (2019) aroma yang dihasilkan saat fermentasi kedelai dikarenakan pemecahan substrat dalam kedelai menjadi senyawa yang lebih sederhana yang bersifat volatil. Perbedaan aroma yang dihasilkan dapat disebabkan oleh peran mikroba selama fermentasi. Menurut Barus dkk. (2008) perbedaan jumlah dan jenis mikroorganisme berpengaruh terhadap citarasa produk fermentasi yang dihasilkan. 


\section{Tekstur}

Hasil analisis ragam pada Tabel 2 menunjukkan bahwa perlakuan lama perebusan berpengaruh sangat nyata $(\mathrm{P}<0,01)$ terhadap tekstur kedelai terfermentasi. Nilai rata-rata tekstur tertinggi yaitu pada perlakuan P5 (180 menit) sebesar $4,00 \%$ dengan kriteria sangat empuk dan nilai rata-rata terendah yaitu pada perlakuan P1 (60 menit) sebesar $1,40 \%$ dengan kriteria tidak empuk.

Pada Tabel 2 dapat dilihat bahwa terjadi perubahan tekstur seiring dengan bertambahnya lama perebusan, yakni dari tidak empuk sampai empuk. Hal ini dikarenakan semakin lama perebusan akan membuat jaringan di dalam kacang kedelai menjadi lunak, dikarenakan air yang masuk ke dalam kacang kedelai. Selain itu kandungan selulosa yang terdapat pada kedelai juga dapat mempengaruhi tekstur kedelai. Hal ini didukung oleh penelitian yang dilakukan oleh Purba, dkk, (2013) yang menyatakan bahwa tekstur kedelai pada saat fermentasi akan menjadi lunak atau lembut karena terjadi penurunan selulosa menjadi bentuk yang sederhana.

\section{Penerimaan Keseluruhan}

Hasil analisis ragam menunjukkan bahwa perlakuan lama perebusan berpengaruh sangat nyata $(P<0,01)$ terhadap penerimaan keseluruhan kedelai terfermentasi. Berdasarkan Tabel 3 hasil menunjukkan bahwa nilai rata-rata uji hedonik pada kedelai terfermentasi dengan berbagai perlakuan, berkisar antara $1,65 \%$ (tidak suka) hingga 5,00 (suka). Penerimaan keseluruhan merupakan angka yang menunjukkan seberapa besar suatu produk dapat diterima oleh panelis. Penilaian penerimaan keseluruhan umumnya merupakan gabungan dari semua aspek seperti warna, aroma dan tekstur dari kedelai terfermentasi.

Berdasarkan hasil pada Tabel 2 (Nilai ratarata uji skoring kedelai terfermentasi) dan Tabel 3 (Nilai penerimaan keseluruhan kedelai terfermentasi), dapat dilihat bahwa nilai tertinggi diperoleh pada perlakuan lama perebusan 150 menit. Maka perebusan 150 menit merupakan perlakuan yang menghasilkan karakteristik kedelai terfermentasi yang terbaik. Hasil penelitian dengan perlakuan terbaik dilanjutkan dengan membandingkan kedelai sebelum fermentasi, kedelai terfermentasi dari laboratorium dan kedelai terfermentasi dari produsen, untuk melihat perbedaan nilai gizi dengan metode pembuatan berbeda.

\section{Hasil Analisis Kedelai Terfermentasi dengan Metode Pembuatan Berbeda}

Nilai rata-rata kadar air, kadar abu, kadar protein, kadar lemak dan kadar karbohidrat dari kedelai terfermentasi dengan metode pembuatan berbeda dapat dilihat pada Tabel 4 .

\section{Kadar Air}

Kadar air dalam proses produksi sere kedele dapat mempengaruhi kualitas akhir produk yang dihasilkan. Hasil perbandingan nilai gizi pada Tabel 4 menunjukkan bahwa kedelai terfermentasi dengan metode pembuatan berbeda berpengaruh nyata $(\mathrm{P}<0,05)$. Berdasarkan data pada Tabel 4 hasil menunjukkan bahwa nilai rata-rata kadar air terbesar yaitu pada kedelai sebelum fermentasi yaitu $31,14 \%$ dan kadar air terendah yaitu pada kedelai setelah fermentasi dari produsen sebesar 26,79\%. Hal ini disebabkan karena saat perebusan, 
air akan masuk ke dalam biji kedelai sehingga menambah kadar air biji kedelai tersebut. Akan tetapi ketika dilakukan fermentasi, kandungan air di dalam biji kedelai akan menurun. Pada tahap fermentasi terjadi akumulasi panas sehingga air menguap yang menyebabkan kadar air berkurang (Walianingsih, 2015). Selain itu menurut Affandi dan Yunita (2011) penurunan kadar air disebabkan karena adanya aktivitas air (Aw) yang tinggi selama fermentasi, sehingga mikroba akan tumbuh secara optimal dan proses metabolisme tersebut memerlukan air untuk memecah substrat yang terdapat di dalam kedelai. Pada kedelai terfermentasi yang diproduksi oleh produsen, kadar air memiliki nilai yang lebih rendah dibandingkan dengan kedelai terfermentasi yang diproduksi di laboratorium. Hal ini dikarenakan proses fermentasi yang dilakukan oleh produsen, menggunakan wadah dari bambu berukuran besar yang memiliki banyak lubang pada setiap sisinya, sehingga air yang dihasilkan dari pemecahan substrat akan keluar dengan mudah melalui lubanglubang tersebut.

Tabel 4. Nilai rata-rata kadar air, kadar abu, kadar protein, kadar lemak dan kadar karbohidrat dari kedelai terfermentasi dengan Metode Pembuatan Berbeda

\begin{tabular}{|c|c|c|c|c|c|}
\hline $\begin{array}{l}\text { Lama perebusan } \\
\text { (150 menit) }\end{array}$ & $\begin{array}{l}\text { Kadar Air } \\
(\%)\end{array}$ & $\begin{array}{l}\text { Kadar Abu } \\
(\%)\end{array}$ & $\begin{array}{c}\text { Kadar } \\
\text { Protein } \\
(\%)\end{array}$ & $\begin{array}{c}\text { Kadar } \\
\text { Lemak } \\
(\%)\end{array}$ & $\begin{array}{c}\text { Kadar } \\
\text { Karbohidrat } \\
(\%)\end{array}$ \\
\hline $\begin{array}{l}\text { Kedelai } \\
\text { fermentasi }\end{array}$ & $31,14 \pm 0,10^{\mathrm{a}}$ & $\begin{array}{l}1,10 \pm \\
0,02^{b}\end{array}$ & $\begin{array}{c}18,00 \pm \\
1,13^{\mathrm{b}}\end{array}$ & $\begin{array}{c}14,42 \pm \\
0,56^{\mathrm{b}}\end{array}$ & $35,34 \pm 0,29^{\mathrm{a}}$ \\
\hline $\begin{array}{l}\text { Kedelai setelah fermentasi } \\
\text { produksi di laboratorium }\end{array}$ & $31,02 \pm 0,12^{\mathrm{a}}$ & $\begin{array}{c}1,41 \pm \\
0,00^{\mathrm{a}}\end{array}$ & $\begin{array}{l}18,47 \pm \\
0,34^{\mathrm{b}}\end{array}$ & $\begin{array}{l}15,08 \pm \\
0,08^{\mathrm{ab}}\end{array}$ & $34,02 \pm 0,43^{b}$ \\
\hline $\begin{array}{l}\text { Kedelai setelah fermentasi } \\
\text { produksi produsen }\end{array}$ & $26,79 \pm 0,08^{b}$ & $\begin{array}{c}1,45 \pm \\
0,02^{\mathrm{a}}\end{array}$ & $\begin{array}{c}22,49 \pm \\
0,28^{\mathrm{a}}\end{array}$ & $\begin{array}{c}15,65 \pm \\
0,13^{\mathrm{a}}\end{array}$ & $33,62 \pm 0,13^{b}$ \\
\hline
\end{tabular}

Keterangan: Nilai rata-rata yang diikuti oleh huruf yang berbeda pada kolom yang sama menunjukkan perbedaan nyata.

\section{Kadar Abu}

Hasil perbandingan nilai gizi pada Tabel 4 menunjukkan bahwa kedelai terfermentasi dengan metode pembuatan berbeda berpengaruh nyata $(\mathrm{P}<0,05)$. Pada Tabel 4 dapat dilihat bahwa nilai kadar abu tertinggi yaitu pada kedelai terfermentasi yang diproduksi oleh produsen, sebesar $1,45 \%$ dan nilai kadar abu terendah yaitu pada kedelai sebelum fermentasi sebesar $1,10 \%$. Hal ini dikarenakan pada saat perebusan banyak mineral yang terlarut di dalam air kemudian kandungan protein yang terdapat di dalam kacang kedelai akan berikatan dengan mineral selama proses fermentasi, kemudian akan dihidrolisis oleh enzim protease yang dihasilkan oleh mikroba menjadi senyawa yang lebih sederhana, sehingga kadar abu meningkat setelah fermentasi. Pada kedelai terfermentasi yang diproduksi oleh produsen, kadar abu memiliki nilai yang lebih tinggi dibandingkan dengan kedelai terfermentasi yang diproduksi di 
laboratorium. Hal ini dapat disebabkan oleh mikroba yang berperan selama fermentasi berlangsung. Menurut Andarti, dkk (2015), mikroba akan memanfaatkan nutrisi yang telah dipecah menjadi gula sederhana untuk melakukan aktivitas pertumbuhan sehingga pertumbuhan mikroba meningkat. Pertumbuhan mikroba yang lebih banyak pada kedelai terfermentasi dari produsen dapat memecah substrat lebih banyak sehingga dapat menghasilkan mineral yang lebih banyak.

\section{Kadar Protein}

Hasil perbandingan nilai gizi pada Tabel 4 menunjukkan bahwa kedelai terfermentasi dengan metode pembuatan berbeda berpengaruh nyata $(\mathrm{P}<0,05)$. Berdasarkan Tabel 4 hasil menunjukkan bahwa nilai rata-rata kadar protein tertinggi adalah kedelai terfermentasi yang diproduksi oleh produsen sebesar $22,49 \%$ dan nilai terendah adalah kedelai sebelum difermentasi sebesar 18,00\%. Hal ini dikarenakan proses perebusan mengakibatkan denaturasi protein. Kemudian saat dilakukan proses fermentasi, protein mengalami peningkatan yang disebabkan oleh aktivitas mikroba. Mikroba akan memecah protein menjadi senyawa yang lebih sederhana yaitu asam amino dengan bantuan enzim protease. Nilai rata-rata kadar protein pada kedelai terfermentasi dari produsen lebih tinggi dari kedelai terfermentasi yang diproduksi di laboratorium. Hal ini dapat disebabkan karena kedelai terfermentasi dari produsen lebih cepat terjadi pemecahan protein menjadi senyawa yang lebih sederhana selama proses fermentasi berlangsung. Kecepatan pemecahan substrat selama fermentasi salah satunya dipengaruhi oleh ketersediaan oksigen. Wadah bambu yang digunakan selama fermentasi memiliki banyak lubang, sehingga lebih banyak oksigen yang dapat masuk ke dalam wadah. Jika oksigen dalam jumlah yang cukup maka oksigen tersebut akan digunakan untuk pertumbuhan mikroba sehingga lebih cepat substrat terpecah menjadi senyawa sederhana. Menurut Tampubolon (2008) faktor utama yang dapat mempengaruhi pertumbuhan mikroba pada bahan pangan yaitu sumber energi (suplai zat gizi), waktu, suhu dan tersedianya oksigen. Selain itu menurut Rahman (1989), menyebutkan bahwa jika oksigen dalam keadaan cukup jumlahnya serta fermentasi berlangsung terus, maka pada keadaan ini mikroba proteolitik dan lipolitik dapat berkembang biak dengan baik.

\section{Kadar Lemak}

Hasil perbandingan nilai gizi pada Tabel 4 menunjukkan bahwa kedelai terfermentasi dengan metode pembuatan berbeda berpengaruh nyata $(\mathrm{P}<0,05)$. Berdasarkan data pada Tabel 4 hasil menunjukkan bahwa nilai rata-rata kadar lemak terbesar yaitu kedelai terfermentasi dari produsen sebesar $15,65 \%$ dan nilai rata-rata kadar lemak terendah yaitu kedelai sebelum fermentasi sebesar $14,42 \%$. Hal ini dikarenakan proses perebusan menyebabkan terjadi perubahan struktur lemak di dalam kedelai karena terjadi proses hidrolisis lemak, lemak akan diubah menjadi asam lemak bebas dan gliserol. Sedangkan pada saat fermentasi, kadar lemak akan mengalami peningkatan dikarenakan terjadi pemecahan lemak oleh mikroba menjadi asam lemak dan gliserol lalu terakumulasi. Hal ini didukung oleh penelitian yang dilakukan oleh Okorie (2013) bahwa 
peningkatan enzim lipolitik pada medium fermentasi menyebabkan terjadinya hidrolisis lemak menjadi asam lemak dan gliserol sehingga terjadi peningkatan lemak selama proses fermentasi karena pemecahan lemak yang lebih sederhana.

\section{Kadar Karbohidrat}

Hasil perbandingan nilai gizi pada Tabel 4 menunjukkan bahwa kedelai terfermentasi dengan metode pembuatan berbeda berpengaruh nyata $(\mathrm{P}<0,05)$. Berdasarkan data pada Tabel 4 hasil menunjukkan bahwa nilai rata-rata kadar karbohidrat terbesar yaitu pada kedelai sebelum fermentasi sebesar 35,34\% dan nilai rata-rata kadar karbohidrat terendah yaitu kedelai terfermentasi dari produsen sebesar 33,62\%. Perbedaan nilai tersebut dikarenakan pada perebusan hanya sebagian kecil karbohidrat yang hilang sehingga kandungan karbohidrat di dalamnya masih cukup tinggi. Sedangkan pada saat fermentasi, karbohidrat akan digunakan oleh mikroba sebagai sumber energi. Menurut Yamabe dalam Yang, dkk., (2011) proses pemecahan karbohidrat akan terjadi cepat di awal fermentasi, sebab karbohidrat merupakan sumber energi utama bagi mikroba.

\section{Total Mikroba}

Pengujian total mikroba pada penelitian ini dilakukan untuk membandingan total mikroba yang tumbuh dari kedelai terfermentasi yang diproduksi di laboratorium dengan kedelai terfermentasi dari produsen. Pengujian total mikroba dilakukan dengan metode hitung cawan (total plate count) dengan menggunakan media PCA. Adapun hasil perhitungan total mikroba dapat dilihat pada Tabel 5.

Pada Tabel 4 dapat dilihat bahwa total mikroba kedelai terfermentasi yang diproduksi oleh dua tempat berbeda berpengaruh nyata $(\mathrm{P}<0,05)$. Pada Tabel 5 juga dapat dilihat bahwa kedelai terfermentasi dari podusen memiliki total mikroba lebih tinggi dibandingkan dengan kedelai terfermentasi yang diproduksi di laboratorium.

Tabel 5. Total mikroba pada kedelai terfermentasi yang diproduksi di laboratorium dengan kedelai terfermentasi yang diproduksi produsen

\begin{tabular}{cc}
\hline Jenis sampel & Total mikroba (CFU/ml) \\
\hline Kedelai terfermentasi produksi laboratorium & $10,09 \times 10^{8}$ \\
Kedelai terfermentasi produksi produsen & $10,49 \times 10^{8}$ \\
\hline
\end{tabular}

Hal ini diduga karena perbedaan wadah fermentasi yang digunakan. Pada produsen, wadah yang digunakan selama fermentasi menggunakan wadah dari bambu yang telah biasa digunakan dalam memproduksi sere kedele sehari-hari untuk tujuan komersial. Maka kemungkinan besar sudah terdapat banyak mikroba yang tumbuh di dalam wadah dari bambu tersebut, sehingga pada saat fermentasi lebih banyak mikroba yang melakukan pemecahan substrat. Hal ini didukung oleh penelitian yang dilakukan oleh Dewi dan Zuki (2012), menyebutkan bahwa wadah dan lama fermentasi dapat berpengaruh terhadap $\mathrm{pH}$, kadar air, dan jumlah mikroba yang tumbuh di dalam proses fermentasi. 
Selain itu berdasarkan hasil analisis menggunakan Independent Samples T- Test dapat diketahui bahwa $T_{\text {hitung }}>T_{\text {tabel, }}$ dengan begitu terdapat perbedaan rata-rata total mikroba antara kedelai terfermentasi dari produsen dengan kedelai terfermentasi produksi di laboratorium. Hal ini sesuai dengan Sarwono, Jonathan (2015) yang menjelaskan bahwa jika nilai $\mathrm{T}_{\text {hitung }}>\mathrm{T}_{\text {tabel, }}$, maka $\mathrm{H}_{0}$ ditolak dan $\mathrm{H}_{\mathrm{a}}$ diterima, artinya terdapat perbedaan yang signifikan (nyata) antara rata-rata hasil antara kelompok A dengan kelompok B pada suatu penelitian.

\section{KESIMPULAN}

Lama perebusan kedelai berpengaruh sangat nyata $(\mathrm{P}<0,01)$ terhadap kadar air, kadar abu, kadar protein, kadar lemak, kadar karbohidrat, warna, aroma, tekstur, dan penerimaan keseluruhan.

Lama perebusan kedelai 150 menit menghasilkan kedelai terfermentasi dengan karakteristik terbaik, dengan kandungan kadar air 31,02\%, kadar abu $1,41 \%$, kadar protein $18,00 \%$, kadar lemak $15,08 \%$ dan kadar karbohidrat 34,02\%. Adapun karakteristik dari kedelai terfermentasi yang dihasilkan yaitu berwarna coklat muda, beraroma khas kedelai terfermentasi, memiliki tekstur empuk dan penerimaan keseluruhan suka.

\section{DAFTAR PUSTAKA}

Affandi, E dan H, Yunita. 2011. Pemanfaatan Limbah Ampas Kelapa Sawit Sebagai Substrat untuk Sintesis Zat Gizi Melalui Fermentasi Kapang Rhizopus Oligosporus. Penelitian Gizi Makanan. Vol. 34(2) hal. 123-130.

Affandi, E dan M. K. Mahmud. 1985. Pengujian Aktivitas Antibakterial pada Tempe terhadap Bakteri Penyebab Diare. Penelitian Gizi dan Makanan. Vol 8: 46-56.
Andarti, Yuli, I., Wardani, A.K. 2015. Pengaruh Lama Fermentasi Terhadap Karakteristik Kimia, Mikrobiologi, dan Organoleptik Miso Kedelai Hitam (Glycine max (L)). Jurnal Pangan dan Agroindustri. Vol.3 No.3 hal. 889-898.

Ano, T.E. 2018. Analisis Morfologi dan Fisiologi Mikroba (Bakteri) pada Pangan Tradisional Sere kedele yang Dibuat Dengan Dua Cara Berbeda. Skripsi. Fakultas Teknologi Pertanian. Universitas Udayana. Jimbaran.

Barus, T., Suwanto, A., Wahyudi, A.T., Wijaya, H. 2008. Role of Bacteria in Tempe Bitter Taste Formation: Microbiological and Molecular Biological Analysis Based On 16S Rrna Gene. Microbiology Indonesia 2(1):17-21..

Chantawannakul, P., Oncharoen, A., Klanbut K., Chukeatirote, E., and Lumyong, S. 2001. Characterization of Protease of Bacillus strain 38 Isolated From Traditionally Fermented Soybean in Northen Thailand. Science Asia 28:241-248.

Dewi, K, Zuki.M, S. 2012. Pemilihan alat. Prosiding Seminar Nasional Fakultas Pertanian Universitas Bengkulu, 339-340.

Febriani, N.L.C. 2018. Pengaruh Lama Fermentasi Kacang Gude (Cajanus cajan L.) Terhadap Karakteristik Sere Undis. Skripsi. Fakultas Teknologi Pertanian. Universitas Udayana. Jimbaran.

Fennema, O.R. (ed.). 1996. Food Chemistry Third Edition. New York: Marcel Dekker, Inc. (http://zuj.edu.jo).

Halifah, P. 2011. Pengaruh Lama Perebusan Terhadap Kadar Protein Tempe Kacang Tunggak (Vigna Unguiculata). Bionature Vol 12 (1), 15-20.

Keuth, S., Bisping, B. 1994. Vitamin B12 Production by Citrobacter freundii or Klebsiella pneumoniae During Tempeh Fermentation and Proof of Enterotoxin Absence by PCR. Applied and Environmental Microbiology 60(5):14951499.

Koswara, S. 1997. Mengenal Makanan Tradisional. Teknologi dan Industri Pangan Vol. VIII No.2, 74-78.

Kristiningrum, E., Susanto, D.A. 2015. Soybean Tempeh Producers Capability in Implementing SNI 3144:2009. Jurnal Standardisasi 16 (2): 99 -108 .

Kusumawati, I.G.A.W. 2019. Nilai Zat Gizi Makro dan Aktivitas Antioksidan Tempe Kedelai (Glycine Max L.) Kombinasi Biji Kecipir (Psophocarpus Tetragonolobus L.). Jurnal Ilmu Dan Teknologi Pangan. Vol 5 No 2 hal. 486495. 
Kholis, N dan Yanti, D.V.A. 2011. Terapi Trombolis Endogen dengan Diet Natto Berbasis KacangKacangan Lokal Inferior Pada Model Tikus (Rattus norvegicus) Aterogenik. Jurnal Teknologi Pertanian. Vol 12 No.1 hal. 8-15.

Mulyatiningsih, E. 2007.Teknik-Teknik Dasar Memasak. Yogyakarta: Universitas Negeri Yogyakarta.

Nugroho, A. D. 2007. Perubahan Sifat Fisika, Kimia dan Mikrobiologi Biji Kedelai Selama Pembuatan Tempe Cara Limbah Minimal. Skripsi. Fakultas Teknologi Pertanian. UGM. Yogyakarta.

Okorie, S.U., F. Ehirim, C. Umelo, A. Ihemeje, and C. C. Ekwe. 2013. Evaluation of Quality Characteristics of Composite Diets Prepared From Sprouted and Fermented Millet and Bredfruit Seed Flours. Global Advanced Research Journal of Agricultural Science 2 Vol (4): 109-115. (http://garj.org).

Purba, Lely, S., Sentosa, G., dan Mimi, N. 2013. Perbandingan Berat Kacang Kedelai Bergerminasi dan Biji Nangka dan Konsentrasi Laru pada Pembuatan Tempe. Jurnal Rekayasa Pangan. Vol.I.No.2 hal. 50-60.

Rahman, A. 1989. Pengantar Teknologi Fermentasi. Pusat Antar Universitas Pangan dan Gizi. Bogor. IPB.

Santoso. 2005. Teknologi Pengolahan Kedelai (Teori dan Praktek). Universitas Widyagama. Malang.

Sarti, M. Y., Lestari, S. D., Rinto, dan Wulandari. 2019. Studi Kesukaan Panelis Terhadap Tempe dari Biji Lotus (Nelumbo nucifera) dan Kedelai (Glycine max). Jurnal Fishtech. Vol. 8, No. 2:3441.

Sarwono, Jonathan. 2015. Rumus-rumus Populer dalam SPSS 22 untuk Riset Skripsi. Yogyakarta: Andi Offset. Hal 152.

Soekarto, S. T. 1985. Penilaian Organoleptik. Bharata Karya Aksara, Jakarta.

Sudarmadji, S., Suhardi, dan B, Haryono. 1997. Prosedur Analisa untuk Bahan Makanan dan Pertanian. Liberty Yogyakarta. Yogyakarta.
Sundari, Dian, Almasyhuri, dan L. Astuti. 2015. Pengaruh Proses Pemasakan Terhadap Komposisi Zat Gizi Bahan Pangan Sumber Protein. Media Litbangkes, Vol.25 No.4 hal. 235-242.

Suprapti, M. L. 2003. Pembuatan Tempe. Teknologi Pengolahan Pangan. Kanisius. Yogyakarta.

Tampubolon, Komariah. 2008. Mikroorganisme dalam Pangan Laut. Fakultas Perikanan dan Ilmu Kelautan. Institut Pertanian Bogor. (http://repository.ipb.ac.id). Diakses pada tanggal 26 Desember 2020.

Walianingsih, E.J. 2015. Pengaruh Lama Fermentasi Kedelai Terhadap Karakteristik Sere kedele. Jurnal Ilmu dan Teknologi Pangan, Vol. 1 hal 19.

Winarno, F. G. 2004. Kimia Pangan dan Gizi. PT. Gramedia Pustaka Utama. Jakarta.

Winarno, F. G. 1997. Kimia Pangan dan Gizi, PT. Gramedia Widjang.

Yang, H. J., S. Park, V. Pak, K.R. Chung, dan D.Y. Kwon. 2011. Fermented Soybean Products and Their Bioactive Compounds. Prof. Hany ElShemy (ed). InTech. Croatia.

Yazid, E., dan Nursanti, L. 2006. Penuntun Praktikum Biokimia untuk Mahasiswa. Yogyakarta: Penerbit Andi Offset. Halaman 65-68.

Yunita, M., Hendrawan, Y., dan Yulianingsih, R. 2015. Analisis Kuantitatif Pada Makanan Penerbangan (Aerofood ACS) Garuda Indonesia Berdasarkan TPC (Total Plate Count) dengan Metode Pour Plate. Keteknikan Pertanian Tropis dan Biosistem Vol. 3 No. 3, 237-248.

Yuningsih, Selvi. 2006. Isolasi dan Karakterisasi Protease Dari Bakteri Isolat Natto. Institut Pertanian Bogor.

Zaini, F dan Octa, Z. 2016. Pengaruh Lama Fermentasi Terhadap Nilai $\mathrm{pH}$, Total Asam, Jumlah Mikroba, Protein, dan Kadar Alkohol Kefir Susu Kacang Kedelai (Glycine max (L) Merill). Skripsi. Fakultas Sains dan Teknologi. Universitas Islam Negeri Maulana Malik Ibrahim Malang. 